\title{
Acaricide residues in beeswax after conversion to organic beekeeping methods*
}

\author{
Marco Lodesani, Cecilia Costa, Giorgia SERRA, Roberto Colombo, Anna Gloria \\ SABATINI
}

Consiglio per la Ricerca e la sperimentazione in Agricoltura - Unità di ricerca in apicoltura e bachicoltura, via di Saliceto 80, 40128 Bologna, Italy

Received 22 June 2007 - Revised 21 December 2007 - Accepted 17 January 2008

\begin{abstract}
Beekeepers interested in converting their honey farms to organic management must replace old combs with organic foundations. The experiment described in this paper compares two methods of replacement of old combs, "fast" (5 combs per year) and "slow" ( 2 combs per year), by measuring the levels of acaricide residues in the newly built combs. Tested acaricides were coumaphos (Perizin and Asuntol), fluvalinate (Apistan), and chlorfenvinphos (Supona). Significant differences between the two replacement groups were observed only for the Apistan group in the third year, confirming high lipophilicity of fluvalinate. The residue levels in the new combs three years after beginning the conversion were significantly lower than initial levels for all products. Direct contamination of the combs was highest in Asuntol-treated hives and lowest in Perizin-treated hives. Residues in honey exceeding EU Maximum Residue Limit were found only in the case of Asuntol.
\end{abstract}

\section{Apis mellifera / acaricide / organic beekeeping / residues / wax}

\section{INTRODUCTION}

Beekeeping is one of the Italian agricultural sectors in which the organic production method has registered a great proportion of adherents: data from 2004 showed that about $7 \%$ of beehives were managed according to organic procedures and $12 \%$ of organic farms were beekeeping establishments (ISMEA, 2005). The number of organic beehives rose from 48000 in 2001 to 72000 in 2005 (SINAB, 2006).

According to the EU Regulation N. 1804/1999 (EC, 1999) concerning organic livestock production, confirmed by the new organic production EU Regulation N. 834/2007 (EC, 2007) the conversion of traditionally managed honey farms to organic production methods must be carried out by substituting

Corresponding author: M. Lodesani, marco.lodesani@entecra.it

* Manuscript editor: Jean-Noël Tasei all the combs in the hive with foundation obtained from organic beekeeping. The decree issued by the Italian Ministry of Forestry and Agriculture Policies on 29/03/2001, concerning implementation of Reg. 1804/99, specifies that this substitution should take place within 3 years to limit contamination of the new combs. It has in fact been shown that some acaricides, due to their lipophilic nature, can contaminate both the combs present in the hive during the chemical treatment (direct contamination) and the new combs built by the bees (indirect contamination) even 18 months after the treatment (van Buren et al., 1992). Experiments by Bogdanov et al. (1998) showed that acaricide residues in beehive products decreased according to the order: brood combs $>$ honey combs $\gg$ honey. While acaricide levels in honey are found to be generally lower than the EU accepted MRL levels (EC, 1990), in comb wax the residues tend to accumulate (Bogdanov, 2006). 
Table I. Characteristics of the products used in the experimental hives.

\begin{tabular}{|c|c|c|c|c|c|}
\hline $\begin{array}{l}\text { Commercial } \\
\text { name, } \\
\text { (owner) }\end{array}$ & $\begin{array}{c}\text { Active } \\
\text { ingredient } \\
\text { /concentration }\end{array}$ & $\begin{array}{l}\text { Registered } \\
\text { for use on }\end{array}$ & $\begin{array}{c}\text { Mode of } \\
\text { application }\end{array}$ & $\begin{array}{l}\text { Dose of a.i. } \\
\text { /colony }(\mathrm{g})\end{array}$ & $\begin{array}{l}\text { Location of the } \\
\text { apiary } \\
\text { (region) }\end{array}$ \\
\hline $\begin{array}{l}\text { Apistan, } \\
\text { (Vita Europe) }\end{array}$ & $\begin{array}{l}\text { Fluvalinate } \\
/ 0.8 \mathrm{~g} / \text { strip }\end{array}$ & honeybees & $\begin{array}{c}\text { plastic } \\
\text { strips }\end{array}$ & 1.6 & $\begin{array}{c}\text { Fossombrone } \\
\text { (Marche) }\end{array}$ \\
\hline $\begin{array}{l}\text { Apitol, } \\
\text { (Ciba Geigy) }\end{array}$ & $\begin{array}{l}\text { Cymiazole } \\
/ 21.2 \%\end{array}$ & honeybees & $\begin{array}{l}\text { sugar } \\
\text { solution }\end{array}$ & 2 & $\begin{array}{l}\text { Macomer } \\
\text { (Sardinia) }\end{array}$ \\
\hline $\begin{array}{l}\text { Apivar, } \\
\text { (Novartis) }\end{array}$ & $\begin{array}{l}\text { Amitraz } \\
/ 0.5 \mathrm{~g} / \mathrm{strip}\end{array}$ & honeybees & $\begin{array}{l}\text { plastic } \\
\text { strips }\end{array}$ & 1 & $\begin{array}{c}\text { Castelfranco } \\
\text { (Emilia-Romagna) }\end{array}$ \\
\hline $\begin{array}{l}\text { Asuntol, } \\
\text { (Bayer) }\end{array}$ & $\begin{array}{l}\text { Coumaphos } \\
\text { / } 50 \%\end{array}$ & cattle, dogs & powdered & 0.25 & $\begin{array}{c}\text { Roncadello } \\
\text { (Emilia-Romagna) }\end{array}$ \\
\hline $\begin{array}{l}\text { Bumetran, } \\
\text { (Schering) }\end{array}$ & $\begin{array}{l}\text { Amitraz } \\
\text { / } 200 \mathrm{~g} / \mathrm{L}\end{array}$ & $\begin{array}{l}\text { agriculture } \\
\text { insecticide }\end{array}$ & $\begin{array}{c}\text { wooden } \\
\text { board }\end{array}$ & 0.25 & $\begin{array}{l}\text { S. Felice Panaro } \\
\text { (Emilia-Romagna) }\end{array}$ \\
\hline $\begin{array}{l}\text { Perizin, } \\
\text { (Bayer) }\end{array}$ & $\begin{array}{l}\text { Coumaphos } \\
\text { / } 32 \mathrm{~g} / \mathrm{L}\end{array}$ & honeybees & dripping & 0.03 & $\begin{array}{l}\text { Buttrio } \\
\text { (Friuli) }\end{array}$ \\
\hline $\begin{array}{l}\text { Supona } \\
\text { (Cyanamid) }\end{array}$ & $\begin{array}{c}\text { Chlorfenvinph } \\
\text { os } \\
/ 200 \mathrm{~g} / \mathrm{L}\end{array}$ & cattle & $\begin{array}{l}\text { wooden } \\
\text { board }\end{array}$ & 0.2 & $\begin{array}{l}\text { Cerezzola } \\
\text { (Emilia- } \\
\text { Romagna) }\end{array}$ \\
\hline
\end{tabular}

Indirect contamination of combs occurs because fat-soluble ingredients are spread all over the hive by the bees' legs and bodies. The very thin layer of wax which therefore covers all the inner surfaces of the hive is a "store room" for lipophilic substances, which can pass from here into new wax and propolis (Wallner, 1999) and, if the levels of residues are high, into honey (Kochansky et al., 2001). Contaminated combs can be a source of residues in honey because natural degradation of acaricides in beeswax does not occur. Rather, there is an accumulation due to repeated applications (Wallner, 1999). Thus, in replacing the brood comb wax during the conversion period to the organic production method, there is a real risk of finding high levels of residues in the combs built on organic or residue-free foundations, due to translocation of residues from contaminated combs that were present in the hive during chemical treatment.

Different kinds of replacement of contaminated beeswax were studied in Switzerland by Imdorf et al. (2004), who showed that complete replacement of old combs with new noncontaminated wax was more successful than a partial replacement in decreasing residues of acaricides (bromopropylate, coumaphos, fluvalinate, flumetrin). In the experiment described in this paper we compared two conversion methods in which replacement of old combs took place over 2 or more years. We used a realistic perspective when choosing the acaricides in the experiment, thereby including products not registered for use on bees but commonly used by Italian beekeepers, as confirmed by levels of residues found in commercial beeswax (Costa et al., 2006; Persano Oddo et al., 2006). The experiment also gave us the chance of evaluating the differences in direct and indirect contamination of the selected acaricides.

\section{MATERIALS AND METHODS}

\subsection{Experimental apiaries}

The first step of the experiment was to find seven apiaries in which seven commonly used acaricides (Tab. I) had been used continuously for at least the preceding five years (up to year 2000 included). The test apiaries consisted of 15-20 colonies each. The hives were of the "Dadant-Blatt" kind typically used in Italy. Queen excluders were placed between the brood chamber and the supers. During the replacement experiment, which started in 2001, infestation levels of Varroa destructor were 
controlled according to organic beekeeping methods, with thymol-based products (Apilife $\operatorname{Var} 囚$ ) in August and $50 \mathrm{~mL}$ of a sucrose solution containing $4.2 \%$ of oxalic acid trickled over the top-bars in November or December.

\subsection{Comb replacement}

In each apiary we replaced five combs per year and per hive in the group "fast replacement" and two combs per year and per hive in the group "slow replacement". The two replacement methods were applied to approximately equal numbers of hives in each apiary. In the wax samples collected as a starting point, it was not possible to determine residues of amitraz and cymiazole. Consequently the two replacement methods were applied only to hives treated with the four products: Perizin ${ }^{\circledR}$, Asuntol ${ }^{\circledR}$ (a.i. coumaphos), Apistan ${ }^{\circledR}$ (a.i. fluvalinate) and Supona ${ }^{\circledR}$ (a.i. chlorfenvinphos).

Each beekeeper was provided with an adequate number of frames with residue-free wax foundations, which they inserted in the brood chambers and supers according to the experiment protocol. The new frames were marked and distanced from each other with a pre-existing comb.

\subsection{Sample collection}

Collection of comb, honey cap and honey samples was carried out until 2003. The comb and cap samples were stored at $-20{ }^{\circ} \mathrm{C}$ prior to analysis, the honey samples were stored at $+4{ }^{\circ} \mathrm{C}$.

\subsubsection{Sampling of old combs}

During the autumn of year 2000, in each hive a $5 \mathrm{~cm} \times 15 \mathrm{~cm}$ portion was collected from two 4 year-old combs ("old combs"), to assess the initial contamination level by direct contamination. These combs were sampled also in 2001, and replaced in the last year of conversion.

\subsubsection{Sampling of newly built brood combs}

At the end of each of the three productive seasons 2001-2003 and in each hive, samples of $15 \mathrm{~cm} \times 15 \mathrm{~cm}$ were collected from all new combs built each year on the residue-free foundations and were pooled into a single sample per year and per hive. In 2003 we collected an overall sample of all the new combs built by each colony since the beginning of the conversion.

\subsubsection{Sampling of honey combs, honey caps and honey}

In supers, sampling was carried out in the same way as in the brood chambers (cutting out portion of combs from each hive) in all apiaries only in 2000 and 2001 (Supona was sampled only in 2000). In 2002 samples representing the whole apiary were collected for Asuntol and Perizin, whereas in 2003 the sample was collected only in Asuntol apiary.

Samples of the caps (250 g or more) from the honey combs and samples of the honey $(500 \mathrm{~g})$ produced in each apiary and extracted by centrifugation were also collected.

\subsection{Chemical analyses}

The samples were analysed for presence of residues of the acaricide pertinent to each apiary by the laboratory of the Consiglio per la Ricerca e la sperimentazione in Agricoltura - Unità di ricerca in apicoltura e bachicoltura (certified UNI CEI EN ISO/IEC 17025).

\subsubsection{Samples}

The collected comb portions were oven-melted at $80{ }^{\circ} \mathrm{C}\left( \pm 5^{\circ} \mathrm{C}\right)$, filtered and solidified, and honey residues washed away. Before analysis the wax samples, which weighed at least $6 \mathrm{~g}$, were stored at room temperature.

\subsubsection{Materials and instruments}

Preparation of the extraction samples of wax and honey was carried out with $60 \mathrm{~mL}$ extraction cartridges, diatomaceous earth (ex. EXTRELUT NT20, Merck - Isolute HM-N, IST- Hydromatrix, Varian) and the following solvents for pesticide analysis: acetone, acetonitrile, dichloromethane, cyclohexane, ethyl acetate, isooctane (Carlo Erba). The gas chromatography analysis of the samples was carried out with a Hewlett Packard G1800C 
Table II. Gas chromatography analysis: quantification and qualification mass ions for each active ingredient and the relative ion ratio in the SIM mode.

\begin{tabular}{lccc}
\hline Active ingredients & $\begin{array}{c}\text { ION } \\
\text { Quantification }\end{array}$ & $\begin{array}{c}\text { ION } \\
\text { Qualification }\end{array}$ & $\begin{array}{c}\text { Relative } \\
\text { response (\%) }\end{array}$ \\
\hline 2,4-DMA & 121 & 120 & $90 \pm 7$ \\
2,4-DMF & 120 & 149 & $92 \pm 9$ \\
CYMIAZOLE & 218 & 144 & $41 \pm 4$ \\
CHLORFENVINPHOS & 323 & 325 & $70 \pm 7$ \\
AMITRAZ & 132 & 293 & $65 \pm 7$ \\
COUMAPHOS & 364 & 364 & $39 \pm 4$ \\
FLUVALINATE & 250 & 252 & $35 \pm 4$ \\
\hline
\end{tabular}

equipped with single quadrupole mass detector (GC-MS system). The capillary column used was a DB-35MS $30 \mathrm{~m} \times 0.25 \mathrm{~mm} \times 0.25 \mu \mathrm{m}$ from $\mathrm{J} \& \mathrm{~W}$ Scientific. Reference materials: amitraz, chlorfenvinphos, coumaphos, cymiazole, tau-fluvalinate, 2,4-dimethylaniline (DMA) were bought from Dr Ehrenstorfer; 2,4-dimethylphenylformamide (DMF) from Aldrich. Stock reference materials solutions were prepared in acetonitrile or acetone at a concentration of $1000 \mathrm{mg} / \mathrm{L}$ and were stored at $-20{ }^{\circ} \mathrm{C}$ in the dark.

\subsubsection{Extraction from wax}

For each wax sample a portion of $3 \mathrm{~g}$ was weighed in a beaker and dissolved in an ultrasonic bath with approximately $20 \mathrm{~mL}$ of cyclohexane. $14 \mathrm{~g}$ of diatomaceous earth (a packet of EXTRELUT NT20) was added to the wax and mixed using a glass rod to avoid the formation of clots. The resulting powdered mixture was inserted into the empty column and set with a light pressure. The sample was eluted with approximately $70 \mathrm{~mL}$ of acetonitrile; when the elution was complete the solvent was evaporated in a rotavapor $\left(\theta=50{ }^{\circ} \mathrm{C}\right.$ at low pressure). The residue was dissolved in $1 \mathrm{~mL}$ ( \pm 0.005) of isooctane before injection into the GC-MS system.

\subsubsection{Extraction from honey}

A portion of $10 \mathrm{~g}$ was weighed in a beaker and dissolved with approximately $5 \mathrm{~mL}$ of distilled water. $14 \mathrm{~g}$ of diatomaceous earth (a packet of EXTRELUT NT20) was added to the honey and mixed using a glass rod to avoid the formation of clots. The resulting powdered mixture was inserted into the empty column and set with a light pressure. The sample was eluted with approximately $100 \mathrm{~mL}$ of dichloromethane; when the elution was complete the solvent was evaporated in a rotavapor $(\theta=40$ $45{ }^{\circ} \mathrm{C}$ at low pressure). The residue was dissolved in $1 \mathrm{~mL}( \pm 0.005)$ of acetone before injection into the GC-MS system.

\subsubsection{GC-MS analysis}

One $\mu \mathrm{L}$ of extract was injected on a DB-35MS $30 \mathrm{~m} \times 0.25 \mathrm{~mm} \times 0.25 \mu \mathrm{m}$ in a splitless mode $(\mathrm{t}=60 \mathrm{~s})$. The injector and detector temperatures were $250{ }^{\circ} \mathrm{C}$ and $280{ }^{\circ} \mathrm{C}$ respectively. The oven temperature program was as follows: initially $60{ }^{\circ} \mathrm{C} \times 1 \mathrm{~min}$., then a $20{ }^{\circ} \mathrm{C} / \mathrm{min}$. ramp up to $260^{\circ} \mathrm{C}$ and this temperature is held for $15 \mathrm{~min}$, then a $30{ }^{\circ} \mathrm{C} / \mathrm{min}$ ramp up to $325^{\circ} \mathrm{C}$ and this temperature is held for $5 \mathrm{~min}$. The carrier gas was helium and the flow on the column was $0.8 \mathrm{~mL} / \mathrm{min}$.

The identification of the active ingredient (a.i.) was carried out with full SCAN mode, and the quantification with SIM (selected ion monitoring) mode to enhance the detector sensibility (Korta et al., 2002). Amitraz is an unstable molecule and it degrades into the metabolites 2,4 dimethylaniline (DMA) and 2,4 dimethylphenylformamide (DMF) which are therefore monitored to reveal the presence of amitraz. Quantification was carried out by external standard method. The quantification and qualification mass ions for each a.i. and the relative ion ratio in the SIM mode are reported in Table II. The working reference materials were obtained by dilution of stock reference solutions in extracts of blank wax or blank honey (a blank sample is completely free from residues of the considered a.i.). The detection limits for all acaricides were $10-15 \mu \mathrm{g} / \mathrm{kg}$ for honey and $20-40 \mu \mathrm{g} / \mathrm{kg}$ for wax. 
Table III. Direct and indirect contamination of comb wax. Residues are expressed as mean $(\mu \mathrm{g} / \mathrm{kg}) \pm \mathrm{SE}$. N.D. $=$ not detectable. B.C. $=$ brood combs. H.C. $=$ honey combs. Different letters in each row indicate significant differences for $P<0.001$.

\begin{tabular}{lccccc}
\hline $\begin{array}{l}\text { Product } \\
\text { (active ingredient) }\end{array}$ & $\begin{array}{c}\text { Kind of } \\
\text { combs }\end{array}$ & $\begin{array}{c}\text { Old combs } \\
(2000)\end{array}$ & $\begin{array}{c}\text { New combs } \\
(2001)\end{array}$ & $\begin{array}{c}\text { New combs } \\
(2002)\end{array}$ & $\begin{array}{c}\text { New combs } \\
\text { (overall 2003) }^{\text {ac }}\end{array}$ \\
\hline $\begin{array}{l}\text { Perizin } \\
\text { (coumaphos) }\end{array}$ & B.C. & $240 \pm 51^{\mathrm{a}}$ & $198 \pm 66^{\mathrm{a}}$ & N.D. $^{\mathrm{b}}$ & N.D. $^{\mathrm{b}}$ \\
\cline { 2 - 6 } $\begin{array}{l}\text { Asuntol } \\
\text { (coumaphos) }\end{array}$ & H.C. & $86 \pm 7^{\mathrm{a}}$ & $46 \pm 53^{\mathrm{a}}$ & N.D. & \\
$\begin{array}{l}\text { Apistan } \\
\text { (fluvalinate) }\end{array}$ & B.C. & $4460 \pm 470^{\mathrm{a}}$ & $1060 \pm 260^{\mathrm{b}}$ & $44 \pm 10^{\mathrm{c}}$ & $200 \pm 34^{\mathrm{c}}$ \\
\cline { 2 - 6 } $\begin{array}{l}\text { Supona } \\
\text { (chlorfenvinphos) }\end{array}$ & H.C. & $2880 \pm 260^{\mathrm{a}}$ & $380 \pm 100^{\mathrm{b}}$ & 100 & N.D. \\
& B.C. & $3570 \pm 740^{\mathrm{a}}$ & $1070 \pm 190^{\mathrm{b}}$ & $500 \pm 110^{\mathrm{b}}$ & $370 \pm 61^{\mathrm{b}}$ \\
\hline & H.C. & $965 \pm 53^{\mathrm{a}}$ & $155 \pm 14^{\mathrm{b}}$ & & \\
& B.C. & $730 \pm 110^{\mathrm{a}}$ & $220 \pm 50^{\mathrm{b}}$ & $52 \pm 18^{\mathrm{c}}$ & $29 \pm 6^{\mathrm{c}}$ \\
\hline
\end{tabular}

\subsection{Statistical analyses}

Comparisons between the mean wax residue levels of the two replacement techniques were carried out using one-way analysis of variance (ANOVA). To establish differences among different aged combs of a same group (same a.i.), Scheffé's multiple comparison procedure in GLM analysis was used at the $P=0.05$ significance level. Results are expressed as means \pm s.e.

\section{RESULTS}

\subsection{Direct contamination of old brood combs}

Direct contamination of the wax, which occurs during chemical treatment, was evaluated by analysing residue levels in the old comb samples, collected in year 2000 and 2001.

No residues were detected in any of the year 2000 samples from old combs in the Apivar, Bumetran and Apitol treated hives and the protocol of the experiment was not relevant. For the other a.i. the residue levels are reported in Table III.

The old brood combs from hives treated with Asuntol, Apistan, Supona and Perizin sampled in 2001 were found to contain respectively $3776 \mu \mathrm{g} / \mathrm{kg} \pm 279$ of coumaphos, $3193 \mu \mathrm{g} / \mathrm{kg} \pm 400$ of fluvalinate, $500 \mu \mathrm{g} / \mathrm{kg} \pm$ 115 of chlorfenvinphos and $218 \mu \mathrm{g} / \mathrm{kg} \pm 27$ of coumaphos. These residue levels were slightly lower than the levels found in the same combs sampled in 2000, although no difference was significant.

\subsection{Effects of the replacement method on the residues in brood combs}

Initial levels of residues in the two replacement groups were not significantly different. In 2001 and 2002 no differences between the two replacement groups were evidenced. The only significant difference between the two groups was found in the totality of combs from the Apistan apiary in 2003 (Tab. IV).

\subsection{Indirect contamination of comb wax}

Indirect contamination was estimated by comparing the mean levels of residues contained in the old honey combs and in brood and honey combs built on residue-free foundations during the first years of organic management, i.e. interruption of previously used chemical treatments.

The groups were considered as a whole as the differences between the 2 replacement methods were not statistically significant, with the exception of Apistan in the 2003 overall sampling. Indirect contamination of brood comb wax was highest in the Perizin treated hives, in which the wax from the new combs built and sampled in 2001 contained $82.5 \%$ of coumaphos compared to the old combs (Tab. III), while this proportion was much lower in Asuntol (23.7\%), Apistan (29.7\%) and Supona $(30.0 \%)$ treated hives.

In the supers, indirect contamination of old honey comb wax was highest in the Asuntol 
Table IV. Effects of the replacement method on residues in brood combs. Residues are expressed as mean $(\mu \mathrm{g} / \mathrm{kg}) \pm \mathrm{SE} . \mathrm{n}=$ number of hives. N.D. $=$ not detectable. Different letters in the Apistan (fluvalinate) row indicate significant differences $(P=0.034)$.

\begin{tabular}{lccccc}
\hline \multicolumn{1}{c}{$\begin{array}{c}\text { Product } \\
\text { (active ingredient) }\end{array}$} & $\begin{array}{c}\text { Comb } \\
\text { replacement }\end{array}$ & $\begin{array}{c}\text { Old combs } \\
(2000)\end{array}$ & $\begin{array}{c}\text { New combs } \\
(2001)\end{array}$ & $\begin{array}{c}\text { New combs } \\
(2002)\end{array}$ & $\begin{array}{c}\text { New combs } \\
\text { (overall 2003) }\end{array}$ \\
\hline $\begin{array}{l}\text { Perizin } \\
\text { (coumaphos) }\end{array}$ & FAST & $272 \pm 80, \mathrm{n}=8$ & $154 \pm 69, \mathrm{n}=8$ & N.D., $\mathrm{n}=9$ & $21 \pm 7, \mathrm{n}=23$ \\
\cline { 2 - 6 } $\begin{array}{l}\text { Asuntol } \\
\text { (coumaphos) }\end{array}$ & SLOW & $199 \pm 63, \mathrm{n}=7$ & $329 \pm 14, \mathrm{n}=7$ & N.D., $\mathrm{n}=6$ & N.D., $\mathrm{n}=18$ \\
Apistan & FAST & $4969 \pm 590, \mathrm{n}=12$ & $973 \pm 261, \mathrm{n}=9$ & $37 \pm 14, \mathrm{n}=12$ & $183 \pm 37, \mathrm{n}=12$ \\
\cline { 2 - 6 } (fluvalinate) & SLOW & $3588 \pm 728, \mathrm{n}=7$ & $1260 \pm 461, \mathrm{n}=7$ & $56 \pm 20, \mathrm{n}=7$ & $213 \pm 49, \mathrm{n}=21$ \\
Supona & FAST & $3787 \pm 1448, \mathrm{n}=5$ & $913 \pm 247, \mathrm{n}=6$ & $139 \pm 65, \mathrm{n}=4$ & $205 \pm 44, \mathrm{n}=10^{\text {a }}$ \\
\cline { 2 - 6 } (chlorfenvinphos) & SLOW & $3475 \pm 886, \mathrm{n}=8$ & $1256 \pm 303, \mathrm{n}=5$ & $316 \pm 60, \mathrm{n}=8$ & $468 \pm 87, \mathrm{n}=16^{\mathrm{b}}$ \\
\hline
\end{tabular}

treated hives $(64 \%$ of the residues contained in the corresponding brood combs), followed by Perizin (36\%), Apistan (27\%) and Supona (3\%). As can be seen in Table III, absolute values of residues in old honey combs were highest in Asuntol treated hives, followed closely by Apistan and then by Perizin and Supona, both with residue levels under $100 \mu \mathrm{g} / \mathrm{kg}$. Indirect contamination of honey combs built on residue-free foundations in 2001 was highest in Perizin treated hives $(53 \%$ of the residues contained in the old honey combs of 2000) and lowest in Asuntol (although the latter had the highest absolute values), followed closely by Apistan.

Residues in the honey caps were the following:

- Perizin: only the sample from 2001 (cappings from old and new wax together) had residues of coumaphos (32 $\mu \mathrm{g} / \mathrm{kg}$ ), whereas in the cappings sampled in the following years no residues were detected.

- Asuntol: in 2001 the cappings from the new "organic" combs were kept separate from the caps of the old honey combs. A strong decrease of residues $(94 \%)$ in the cappings sampled in 2002 was registered. In 2003 no residues were detected in the organic cappings.

- Apistan: in 2001 organic and traditional cappings were pooled and high levels of fluvalinate residues were found $(2553 \mu \mathrm{g} / \mathrm{kg})$. In the 2002 samples the "non-organic" caps and "organic" cappings contained $23 \%$ and $11 \%$ of this amount, respectively.

- Supona: none of the samples collected in 2001, 2002 and 2003 contained detectable levels of residues.

Residues of the a.i. in the honeys extracted from the supers of each apiary were found only in the samples from the Asuntol apiary in the first year of the experiment (2001). Residues of coumaphos were present in the 3 honey crops: Tilia honey contained $23 \mu \mathrm{g} / \mathrm{kg}$, multiflora honey $138 \mu \mathrm{g} / \mathrm{kg}$, which is more than the EU MRL of $100 \mu \mathrm{g} / \mathrm{kg}$, and honeydew honey $35 \mu \mathrm{g} / \mathrm{kg}$.

\section{DISCUSSION}

\subsection{Direct contamination}

The absence of residues in the samples from the Apivar and Bumetran apiaries are probably due to the unstable nature of the a.i. amitraz and its metabolites. According to EMEA (European Agency for the Evaluation of Medicinal Products) residues of amitraz in honey were stable for up to 4 months when samples were stored at $-20{ }^{\circ} \mathrm{C}$ but not when stored at $+25{ }^{\circ} \mathrm{C}$. In our case, although the samples were stored at $-20{ }^{\circ} \mathrm{C}$, breakdown of the a.i. must have occurred, confirming previous observations that beeswax seems to have an accelerating effect on the degradation of amitraz (Wallner, 1999; Korta et al., 2002). The absence of cymiazole residues in the wax 
samples from the Apitol apiary is in accordance with the hydrophilic nature of this a.i.

In the samples from the hives treated with Perizin, Asuntol, Apistan and Supona, the lack of significant difference in residue levels of directly contaminated combs from the year of the last chemical treatment in 2000 to the next confirmed the persistency of all these acaricides in beeswax.

\subsubsection{Asuntol and Perizin (coumaphos)}

Residues of coumaphos in wax due to direct contamination are 20 times lower when the acaricide treatment is carried out with Perizin rather than with Asuntol. The different contamination caused by these two products is due not only to the smaller amount of coumaphos that is inserted into the hive during the treatment (on average $32 \mathrm{mg}$ with Perizin and $250 \mathrm{mg}$ with Asuntol, corresponding to a ratio of $1: 8)$ but also to the different coformulants present in the commercial products, which can explain why the ratio of coumaphos residues in Perizin versus Asuntol treated hives is 1:19 in the brood combs and 1:33 in the honey combs. Asuntol contains emulsifying agents and caolin, which encourage the formation of molecular aggregates that guarantee its adhesiveness, necessary to cling to the fur of the animals for which this product is registered. In the beehive Asuntol could form micro-colloids which would adhere randomly to the surface of the combs; the tensioactive coformulants would therefore be responsible for a chemical integration of the powder into the wax, causing a more difficult transfer of coumaphos by the bees.

\subsubsection{Apistan (fluvalinate)}

The residue levels we found in the wax from combs present during the chemical treatment correspond to those reported by Bogdanov et al. (1998). Apistan was the registered product that caused the highest levels of residues. Following the discovery of development of strains of fluvalinate-resistant mites (Lodesani et al., 1995) use of Apistan in Italy decreased, but in recent years its use has been re-adopted in some regions.

\subsubsection{Supona (chlorfenvinphos)}

The initial sampling carried out in the Supona treated apiary showed that use of this product causes presence of residues of its a.i. in brood comb wax, at a level lower than Asuntol and Apistan but higher than Perizin. However, it must be noted that the product was not sprinkled or sprayed inside the hive, but applied to strips placed at the hive entrance for the bees to walk on, so that direct contact of the product on the combs did not occur.

In recent years chlorfenvinphos has been increasingly employed to control Varroa destructor, as indicated by the growing percentage of wax samples contaminated by residues (17\% in 2003) (Costa et al., 2006; Gallina et al., 2006). The acaricide potency of chlorfenvinphos is about 50 times that of coumaphos (Milani and Della Vedova, 1996). Therefore, the amount of a.i. needed to control $V$. destructor is correspondingly lower and this also explains the low level of residues. The current treatment tendency, however, is to place the strips inside the hive. Consequently a greater number of bees are likely to contact the product and result in a rise of chlorfenvinphos residues, as the hydrocarbons and the fatty acids of the bees cuticle will transfer the product to the brood combs with greater intensity.

\subsection{Replacement experiment}

Fluvalinate was the only acaricide for which significant differences were observed through the experiment of comb replacement. Significant differences between the two groups were observed only in the third year from the beginning of the conversion. The slow comb replacement resulted in more than twice the residues in the wax of combs in the fastreplacement group. This result could be due to the higher persistence of fluvalinate, the most lipophilic of all the acaricides considered in the study (Bogdanov et al., 1998). 
From our replacement experiment, it is strongly recommended that beekeepers converting to organic production who have used Apistan to control V. destructor, should adopt a fast replacement method of the brood combs, since in the third year the slow replacement (two combs per year) results in unacceptable residue levels for organic beekeeping. On the other hand, when Supona, Asuntol or Perizin have been used by beekeepers, the method of comb replacement will not influence the residue levels at the end of the conversion, which will be very close to the detection level in the Supona and Perizin hives, and close to $200 \mu \mathrm{g} / \mathrm{kg}$ in the Asuntol hives. In experiments by Imdorf et al. (2004), a gradual replacement of combs with initial residue levels of acaricides (bromopropylate, coumaphos, fluvalinate, flumetrin) lower than $800 \mu \mathrm{g} / \mathrm{kg}$, resulted in no detectable residues in the second year of replacement. Our study partially confirmed this data in Perizin and Supona hives, as initial residue levels lower than $800 \mu \mathrm{g} / \mathrm{kg}$ a.i. in both replacement groups resulted in residue levels in the second year of replacement, lower than the detection level used by Imdorf et al. $(250 \mu \mathrm{g} / \mathrm{kg})(2004)$.

\subsection{Indirect contamination}

\subsubsection{Asuntol and Perizin (coumaphos)}

The transfer of coumaphos residues from old combs to new combs was much greater in the Perizin-treated hives than in the Asuntoltreated hives, in agreement with the aggregation hypothesis whereby coumaphos carried by Asuntol is less mobile than when carried by Perizin (see Sect. 4.1.1). Experiments by van Buren et al. (1992) showed that $\sim 10 \%$ of coumaphos residues from Perizin in wax were due to indirect contamination originating from the bees' fat cells, whereas residual contamination of virgin wax is due to proximity with old, contaminated combs, which "exchange" coumaphos with the hydrocarbons of bees' cuticle. The Perizin water emulsion which is sprinkled in the hive evidently favours the spreading of coumaphos over the whole surface of the combs, making the a.i. more available to being transported by the bees' body even a year after the treatment and thereby increasing the probabilities of contamination of new wax. Nevertheless at the end of our experiment the levels of residues in both brood and honey combs from Perizin hives were about 10 times lower than residues in Asuntol ones. Residues of coumaphos in the old honey combs were higher in Asuntol hives and it is significant also that the only honey samples containing acaricide residues were the ones from the Asuntol apiary in the first year of the experiment. In agreement to Wallner's (1995) and Kochansky's et al. (2001) findings, we confirmed that high concentrations of coumaphos in wax cause the transfer of detectable levels of residues to the honey extracted for human consumption.

\subsubsection{Apistan (fluvalinate)}

When the samples from the Apistan apiary were considered as a whole we observed that indirect contamination of brood comb wax from fluvalinate was almost $30 \%$, higher than that of Asuntol, lower than Perizin and the same as Supona. Thus, it appears that Apistan is responsible for both high levels of direct and indirect contamination, confirming the product's strong lipophilic nature and suggesting high mobility in the wax.

\subsubsection{Supona (chlorfenvinphos)}

Chlorfenvinphos showed the lowest mobility in the hive, as residues of this a.i. in honey comb wax and honey caps were the lowest in both absolute and relative terms.

With this study we have shown that, independent of the speed of replacement, comb wax at the end of experiment contained residues of the previously used acaricides (compared to the initial concentrations in wax: 4\% Supona, 5\% Asuntol, 8\% Perizin and $10 \%$ Apistan). This study confirms that a total brood comb renewal over 2 years will not guarantee a complete absence of residues of some of the products currently used in hives. For many beekeepers, however, simultaneous complete substitution of the old combs in all 
their hives is very difficult, both technically (time consuming) and economically (equipment, residue-free foundations) and a longer conversion period is considered more practical. The decision adopted by many Organic Farming Control Bodies in Italy, to accept certain levels of residues in brood comb wax in the initial years of organic management, therefore appears justified. The same allowance is also valid for the honey-cap wax melted into foundations by converting beekeepers.

Our study confirmed that using coumaphos in the unregistered product Asuntol may contaminate honey for human consumption.

\section{ACKNOWLEDGEMENTS}

We wish to thank the beekeepers who contributed their time and hives to this project, in particular Roberto Guidetti, Giovanni Scozzoli and Riccardo Durì.

\section{Résidus d'acaricides dans la cire d'abeille après la conversion aux méthodes de l'apiculture bio- logique.}

\section{Apis mellifera / cire / acaricide / résidus / apicul- ture biologique}

Zusammenfassung - Akarizidrückstände im Bienenwachs nach der Umstellung auf die ökologische Bienenhaltung. Die ökologische Bienenhaltung hat in Italien seit Einführung der Richtlinien der Europäischen Gemeinschaft zur ökologischen Tierhaltung (Reg. N. 1804/1999, nun ersetzt durch Reg. N. 834/2007) zugenommen. Zur Umstellung müssen Bienenhalter alte Waben innerhalb von drei Jahren durch rückstandsfreie Mittelwände ersetzen. Auf Grund der fettlöslichen Natur der meisten Milbenbehandlungsmittel reichern sich Rückstände im Wachs an und neue Waben sind dem Risiko einer indirekten Kontamination ausgesetzt. In dem in diesem Artikel beschriebenen Experiment wurden zwei Umstellungsmethoden verglichen, bei denen der Ersatz der alten durch neue Waben über zwei oder mehr Jahre hinweg stattfand. Die von den italienischen Imkern am häufigsten verwendeten Akarizide wurden in Betracht gezogen, darunter auch kommerzielle Produkte, die für die Anwendung bei Honigbienen nicht zugelassen sind: Coumaphos (Perizin und Asuntol), Fluvalinat (Apistan), Chlorfenvinphos (Supona) (Tab. I). Das rasche Auswechseln der Waben führte im dritten Jahr der ökologischen Bienenhaltung nur bei
Apistan zu einer verringerten insgesamten Kontamination (Tab. IV), dies ist vermutlich auf die hohe Lipophilie von Fluvalinat zurückzuführen. Die erhaltenen Daten wurden zusätzlich genutzt, um direkte und indirekte Kontamination durch die untersuchten Akarizide zu vergleichen. Die Analyse der während der nichtökologischen Bienenhaltung in den Völkern vorhandenen Waben zeigte, dass die Kontamination bei Asuntol am höchsten war, während sie in den mit Perizin behandelten Völkern am geringsten war (Tab. III). Die indirekte Kontamination von neu gebauten Waben war bei Perizin am höchsten $(\sim 83 \%)$ und lag bei den anderen Akariziden zwischen $20 \%$ und $30 \%$ (Tab. III). Der Rückstandsgehalt der frisch gebauten Waben drei Jahre nach der Umstellung war bei allen Produkten signifikant geringer als der Anfangsgehalt, in den meisten Fällen lag er unterhalb der von den ökologischen Kontrollinstanzen übergangsweise zugelassenen Grenzwerten. Die indirekte Kontamination des Honigwabenwachses während der nichtökologischen Bienenhaltung war in den mit Asuntol behandelten Völkern am höchsten. Neue, während des Experiments auf rückstandsfreien Mittelwänden gebaute Waben wurden ebenfalls kontaminiert, allerdings war der Rückstandgehalt im dritten Jahr nach Beginn der Umstellung sehr gering oder nicht mehr nachweisbar. Im Honig wurden die EU MRL überschreitenden Rückstandsgehalte ausschließlich in dem mit Asuntol behandelten Bienenstand und nur im ersten Jahr des Experimentes gefunden.

Apis mellifera / Akarizide / ökologische Bienenhaltung / Rückstände / Wachs

\section{REFERENCES}

Bogdanov S. (2006) Contaminants of bee products, Apidologie 37, 1-18.

Bogdanov S., Kilchenmann V., Imdorf A. (1998) Acaricide residues in some bee products, J. Apic. Res. 37, 57-67.

Costa C., Lodesani M., Serra G., Colombo R. (2006) Monitoraggio di residui di acaricidi in cera italiana, Apoidea 3, 10-17.

EC (1990) Council Regulation N. 2377/90 of 26 June 1990 laying down a Community procedure for the establishment of maximum residue limits of veterinary medicinal products in foodstuffs of animal origin, Off. J. Eur. Union L 22, 18/08/1990, 1-8 (As amended by Regulations (EEC) N 2034/96 (OJ L 272 25.10.1996 p. 2), N 2686/98 (OJ L 33712.12 .1998 p. 20), N 1931/99 (OJ L 240 10.09.1999 p. 3) and $\mathrm{N} 2393 / 99$ (OJ L 290 12.11.1999 p. 5)).

EC (1999) Council Regulation N. 1804/1999 of 19 July 1999 supplementing Regulation (EEC) 
N. 2092/91 on organic production of agricultural products and indications referring thereto on agricultural products and foodstuffs to include livestock production, Off. J. Eur. Union L 222 24.8.1999, 1-28.

EC (2007) Council Regulation N. 834/2007 of 28 June 2007 on organic production and labelling of organic products and repealing Regulation (EEC) N. 2092/91, Off. J. Eur. Union L 189, 20.07.2007, $1-23$.

Gallina A., Baggio A., Mutinelli F. (2006) The use of chlorfenvinphos: a matter of concern for Italian beekeeping, Proc. 2nd Eur. Conf. of Apidology, Prague, 10-14 September 2006, p. 86.

Imdorf A., Bogdanov S., Kilchenmann V. (2004) Sostituzione della cera nel quadro dell'apicoltura biologica, L'Ape 87, 14-19.

ISMEA (2005) L'evoluzione del mercato delle produzioni biologiche, Soc. Ed. Imago Media, Dragoni (CE).

Kochansky J., Wilzer K., Feldlaufer M. (2001) Comparison of the transfer of coumaphos from beeswax into syrup and honey, Apidologie 32, 119-125.

Korta E., Bakkali A., Berrueta L.A., Gallo B., Vicente F., Bogdanov S. (2002) Determination of amitraz and of other acaricide residues in beeswax, Anal. Chim. Acta 475, 97-103.
Lodesani M., Colombo M., Spreafico C. (1995) Ineffectiveness of Apistan treatment against the mite Varroa jacobsoni Oud in several districts of Lombardy (Italy), Apidologie 26, 67-72.

Milani N., Della Vedova G. (1996) Determination of the LC50 in the mite Varroa jacobsoni of the active substances in Perizin $₫$ and Cekafix $₫$, Apidologie 27, 67-72.

Persano Oddo L., Pulcini P., Allegrini F., Ricci L. (2006) Residui di acaricidi nella cera e allevamento biologico, L'Apis 11, 11-16.

SINAB (2006) L'agricoltura biologica in cifre al 31/12/2005 [online] www.sinab.it/allegati_news/ 365/bio_in_cifre_2005.pdf (accessed on 17 January 2008).

Van Buren N.W.M., Marien J., Velthuis H.H.W., Oudejans R.C.H.M. (1992) Residues in beeswax and honey of Perizin, an acaricide to combat the mite Varroa jacobsoni Oudemans (Acari: Mesostigmata), Environ. Entomol. 21, 860-865.

Wallner K. (1995) The use of varroacides and their influence on the quality of bee products, Am. Bee J. $135,817-821$.

Wallner K. (1999) Varroacides and their residues in bee products, Apidologie 30, 235-248. 